\title{
Study of land use classification in an arid region using multispectral satellite images
}

\author{
Chaitanya B. Pande ${ }^{1} \cdot$ Kanak N. Moharir ${ }^{2}$ - S. F. R. Khadri' ${ }^{2}$ Sanjay Patil ${ }^{3}$
}

Received: 23 February 2018 / Accepted: 28 June 2018 / Published online: 18 July 2018

(c) The Author(s) 2018

\begin{abstract}
Rapid urbanization and deforestation have led to increased areas of wasteland in the northern region of the Akola district of Maharashtra, India. This study investigates land use variations in the arid region with the help of multi-temporal images. Land use maps were employed for analysis of different classes using image classification tools in ArcGIS software. Multispectral satellite imagery data were used to create land cover variation maps and land use forecast maps for the study area. The land use classification change maps were produced from LISS-III satellite images and Landsat Enhanced Thematic Mapper Plus (2008 and 2015) using supervised classification techniques. Land use was divided into five major classes, i.e. agricultural land, developed land, wasteland, water bodies, and forestland. We observed significant changes in agricultural and forestland as a result of many factors including population growth, drought conditions, road infrastructure development, flooding, and soil erosion in the arid area. The overall accuracy of the supervised classification was $94.10 \%$ for 2008 and $88.14 \%$ for 2015 , using the kappa method, which was a satisfactory result. The analysis of land use maps in the arid region revealed different patterns of use between 2008 and 2015. The results of this study may be useful for developing and implementing valuable management strategies for resource protection in the study area. These results show the potential for land use planning and development in arid regions using remote sensing and GIS technology.
\end{abstract}

Keywords Land use $\cdot$ Arid region · Satellite images $\cdot$ GIS

\section{Introduction}

Land use and land cover change (LULCC) is an important measurement for assessing global change across a range of spatiotemporal scales (Lambin 1997). LULCC is a widespread, ever-accelerating process largely driven by human actions, and in many cases it also drives changes that affect humans (Agarwal et al. 2001). The increasing scarcity of natural resources is the result of vast agronomic development and demographic pressure. Hence, information on land use/cover and strategies for optimal use are critical for the design, development, and application of land use/cover

Chaitanya B. Pande

Chaitanay45@gmail.com

$1 \quad$ All India Coordinated Research Project for Dryland Agriculture, Dr. PDKV, Akola, India

2 Department of Geology, Sant Gadge Baba Amravati University, Amravati, India

3 Maharashtra Remote Sensing Application Center, Pune, India strategies to meet the growing needs to support basic human and animal health and welfare. This information is also helpful for monitoring the dynamics of LULCC arising from the demands of an increasing population (Pande 2014).

An understanding of LULCC patterns is essential for the management and development of natural resources (Myers 1993). Changes in land use and land cover patterns must be considered from the perspective of complex factors related to technology, demand, and social relationships affecting both ecological capacity and demand, along with the nature of the environment itself (Verburg et al. 2004). Environmentalists are largely concerned with the effects of LULCC as they pertain to biodiversity and water ecology (Turner et al. 2001; Butt et al. 2015). Variation in land use/cover in a watershed can affect groundwater quality and source. For example, LULCC due to watershed development and management commonly results in higher surface runoff, decreased groundwater recharge, and application of chemicals (Turner et al. 2001). Thus, the determination of land use/cover patterns and their variations in watershed areas is 
vital to the development and management of water properties and land use planning.

However, the increasing development of the world's natural resources has given rise to overexploitation of these resources, leading to deforestation, erosion, and land degradation (Kalaba et al. 2013). Hence, a deeper understanding of the multiple interdependencies between changing land use/cover and the livelihood of rural populations is vital for land use planning and management, which can be facilitated with the use of remote sensing (RS) and GIS-based technology.

RS and GIS have been used to categorize and map LULCC with different technologies and digital data sets. Landsat images in particular have helped in the classification of dissimilar landscapes on a greater scale (Ozesmi and Bauer 2002). Various LULCC detection techniques have recently been established that utilize remotely sensed images and GIS software, and change detection techniques and algorithms have been investigated to determine their advantages and disadvantages. Among these techniques, unsupervised classification, supervised classification, and fuzzy classification are the most commonly applied for image classification, with the help of RS and GIS software (Lu et al. 2004; Rundquist et al. 2001; Zhang et al. 2000). An attempt is made in this study to map out the status of land use/cover of one of the development blocks of the Uttarakhand state, viz., Hawalbagh block of District Almora (Rawat and Kumar 2015). Boori et al. (2014) analyzed land use/cover disturbances caused by tourism using a number of RS and GISbased techniques, including supervised classification. Rawat et al. (2013) also applied the same technique for the Ramnagar town area, Uttarakhand, India, to track changes over the period from 1990 to 2010.

Therefore, the key objective of this research was to use multispectral satellite images to distinguish the extent of changes in the arid area of the Akola district, Maharashtra, India, over a 15-year period for land use mapping to investigate the effects of climate change on land use. Specifically, the study aimed (1) to detect and demarcate different land use categories and LULCC patterns in the watershed from 2008 to 2015 , and to prepare land use forecast maps using multitemporal satellite images of the arid region; (2) to study the integration of GIS with RS in determining the spatial data distribution for different types of LULCC; and (3) to determine the shift in land use classes through comparison of spatial data from land use maps created based on RS and GIS technology.

The arid region has experienced changes in land use as a result of both natural and human activity, which makes it an ideal location in which to evaluate natural processes and anthropogenic activity that drive land use planning and development. The study area has undergone extensive longterm monitoring, providing a sizable volume of land use data regarding the watershed, and spatial distribution and changes over the last four decades have been assessed using unsupervised classiication and satellite images.

\section{Study area}

The study area is located in the northern part of Akola district, Maharashtra, between $77^{\circ} 7^{\prime} 30^{\prime \prime} \mathrm{E}$ and $21^{\circ} 10^{\prime} 0^{\prime \prime} \mathrm{N}$ (Fig. 1). The arid region consists of basaltic rock and undulating topography. A mean sea level (MSL) range of 685-307 m was identified using a digital elevation model and Arc Hydro tools in the GIS domain. The average annual rainfall (over 20 years) at the PKV University Akola Meteorological Station is about $600-800 \mathrm{~mm}$. This area is used for agricultural purposes, but satellite images show that agricultural land use is steadily decreasing. An annual maximum temperature of $42{ }^{\circ} \mathrm{C}$ and minimum temperature of $25^{\circ} \mathrm{C}$ were recorded by the Indian Meteorological Department.

\section{Data collection}

The satellite data used for land use mapping and prediction of land cover is divided into satellite data and ancillary data analysis using unsupervised classification. The ancillary data included field verification data and aerial imagery for land use analysis in the arid region. The field verification data were collected for feature identification using a Garmin Global Positioning System (GPS) during the months of March to October 2008 and 2015. The land use maps were prepared using classification tools, and the overall accuracy of the land use maps was calculated with kappa coefficients using ArcGIS 10.3 software. In the present study, 2 years of high-quality multispectral satellite images were acquired for the month of September through the United States Geological Survey (USGS) Global Visualization Viewer (GloVis) and the National Remote Sensing Centre, Hyderabad. These satellite images were geo-rectified for land use maps and land use forecasting in the arid region for development and planning of LULCC analysis (Table 1).

\section{Methodology}

Geometric correction of the study area was performed by establishing a relationship between the ground coordinate system and the image coordinate system with the help of ERDAS software. Positional values of a few ground control points (GCPs) were collected, and the images were geometrically rectified using polynomial transformation, with a root mean square error (RMSE) of $<1$ pixel. For geo-referencing images, the raw satellite data were co-registered with 

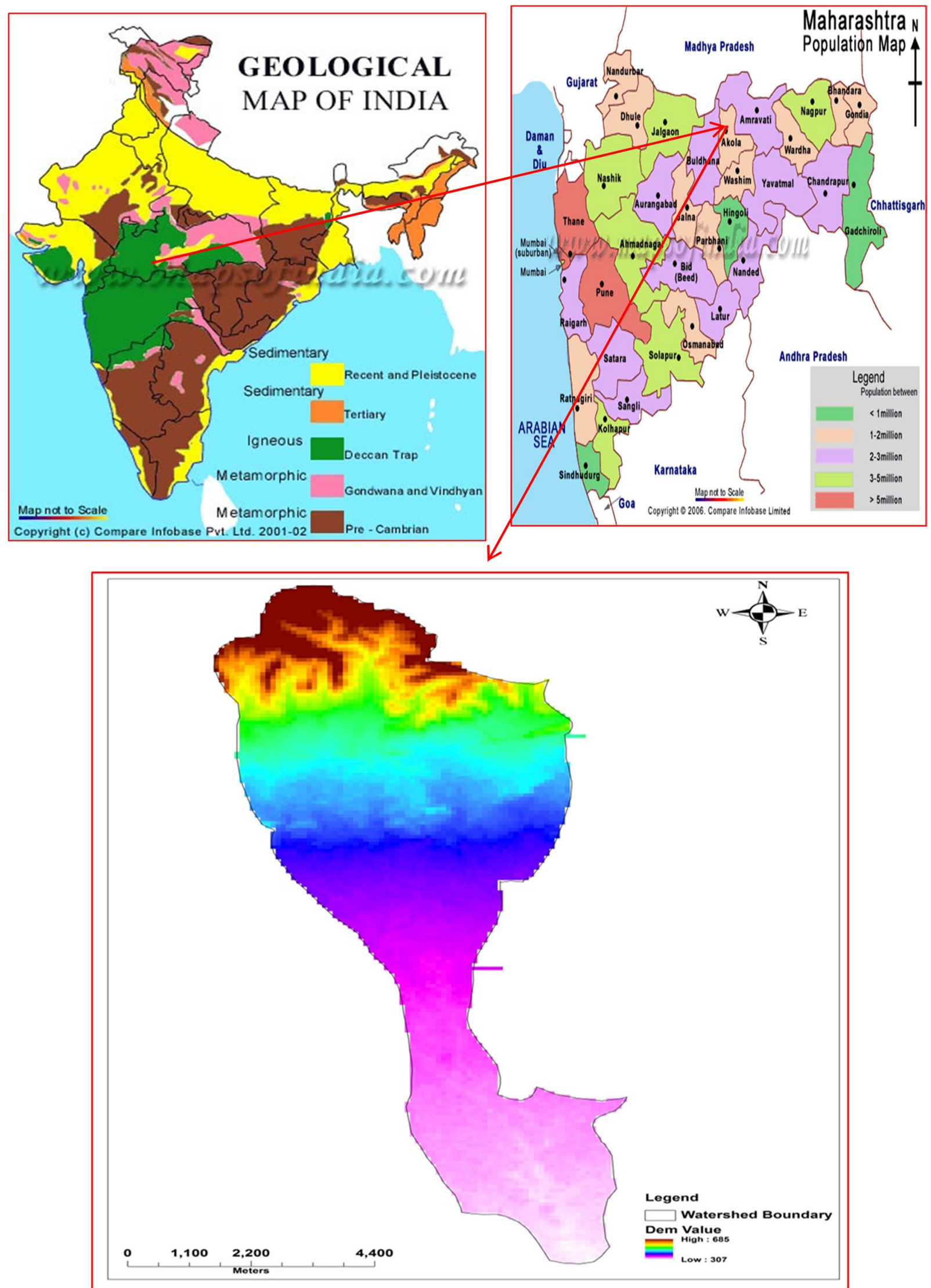

Fig. 1 Location of Ruikhed watershed 
Table 1 Satellite data description

\begin{tabular}{lllll}
\hline Data & $\begin{array}{l}\text { Year of acquisi- } \\
\text { tion }\end{array}$ & Bands/color & Resolution $(\mathrm{m})$ & Source \\
\hline LISS-III & 2008 & $\begin{array}{l}\text { Multispectral/red, } \\
\text { green, and blue } \\
\text { Multispectral }\end{array}$ & 23.5 & www.bhuvan.com \\
Landsat ETM & 2015 & - & 30 & USGS GloVis \\
Toposheets & 1970 & - & 30 & Survey of India \\
DEM data & 2008 & w & www.bhuvan.com \\
\hline
\end{tabular}

LISS-III Linear Imaging Self-Scanning Sensor-III, ETM Enhanced Thematic Mapper

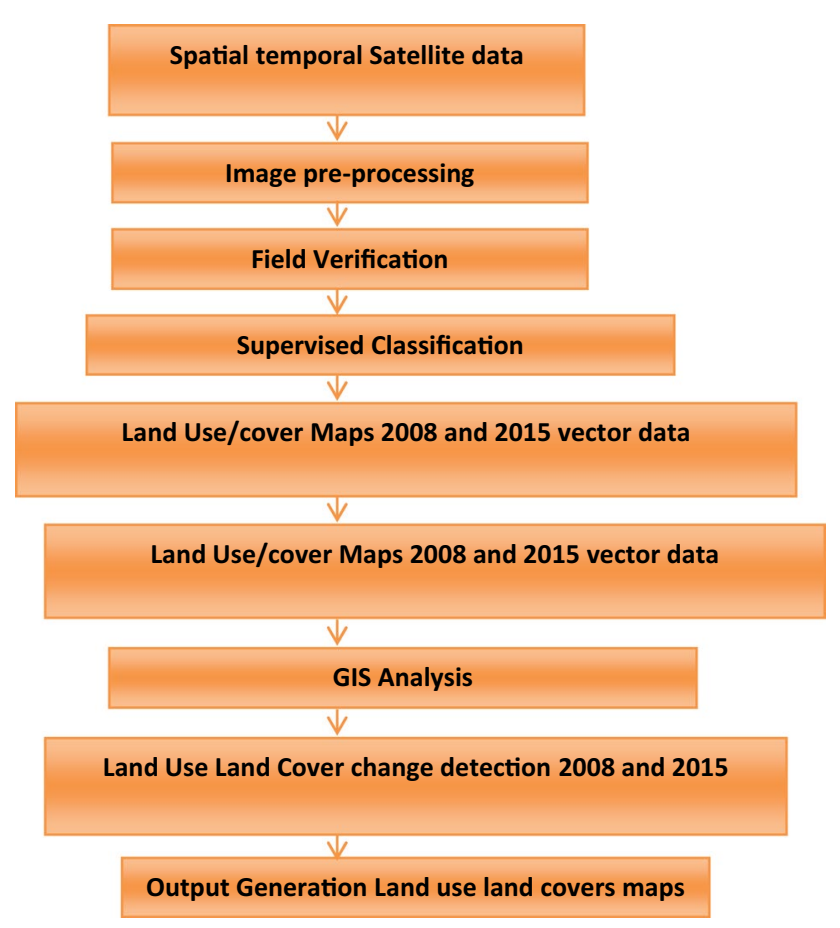

Fig. 2 Methodology used in Ruikhed watershed study

ortho-rectified satellite images from LISS-III and Landsat Enhanced Thematic Mapper Plus (ETM+) data. The satellite images were geo-referenced to the Universal Transverse Mercator (UTM) coordinate system and World Geodetic System (WGS) 1984 datum with the help of image processing and GIS software. In this study, all satellite images were studied by assigning per-pixel signatures and differentiating the watershed into five land use/cover classes on the basis of the specific digital number (DN) value of different landscape elements.

For each of the encoded land use/cover types, training samples were selected by delimiting polygons around representative sites using the Training Sample Manager. Spectral signatures for the respective land use/cover classes resulting from the satellite imagery were verified using the pixels enclosed by these polygons. A satisfactory spectral signature is one confirming that there is "minimal confusion" among the land covers to be mapped (Gao and Liu 2010). Next, a maximum likelihood algorithm was used for supervised classification of the images with the help of ERDAS version 11 software. This is a type of satellite image classification which is mainly measured by the analyst, as the analyst selects the pixels that are representative of the preferred classes.

Field studies - the most important component-were carried out during 2008-2015 to determine classes of land use/cover features in the Ruikhed watershed (Fig. 2). Ground truth verification was collected using satellite image hard-copy prints of the study area, Survey of India topographical maps, and GPS. On-screen digitization was adopted for the land cover mapping, as the delineation of the finer type variation was possible. ERDAS Imagine 2013 was used for visual interpretation and for assigning attributes to individual polygons for various classes. In the first step, agricultural and non-agricultural areas were demarcated separately, and the non-agricultural areas were further classified into different land use/cover types (Table 2). Spatial-temporal changes in land use/cover were calculated using GIS software and ERDAS 11 software.
Table 2 Land use/land cover types on the basis of supervised classification

\begin{tabular}{lll}
\hline S. no. & Land use land cover class & Description \\
\hline 1 & Agricultural land & Crop fields and fallow land \\
2 & Developed land & $\begin{array}{l}\text { Residential, commercial, industrial, transpor- } \\
\text { tation, roads, mixed urban }\end{array}$ \\
3 & Wasteland & Barren land, scrubland \\
4 & Water bodies & River, open water, lakes, ponds, and reservoirs \\
5 & Forestland & Open forest, reserved forest, and dense forest \\
\hline
\end{tabular}




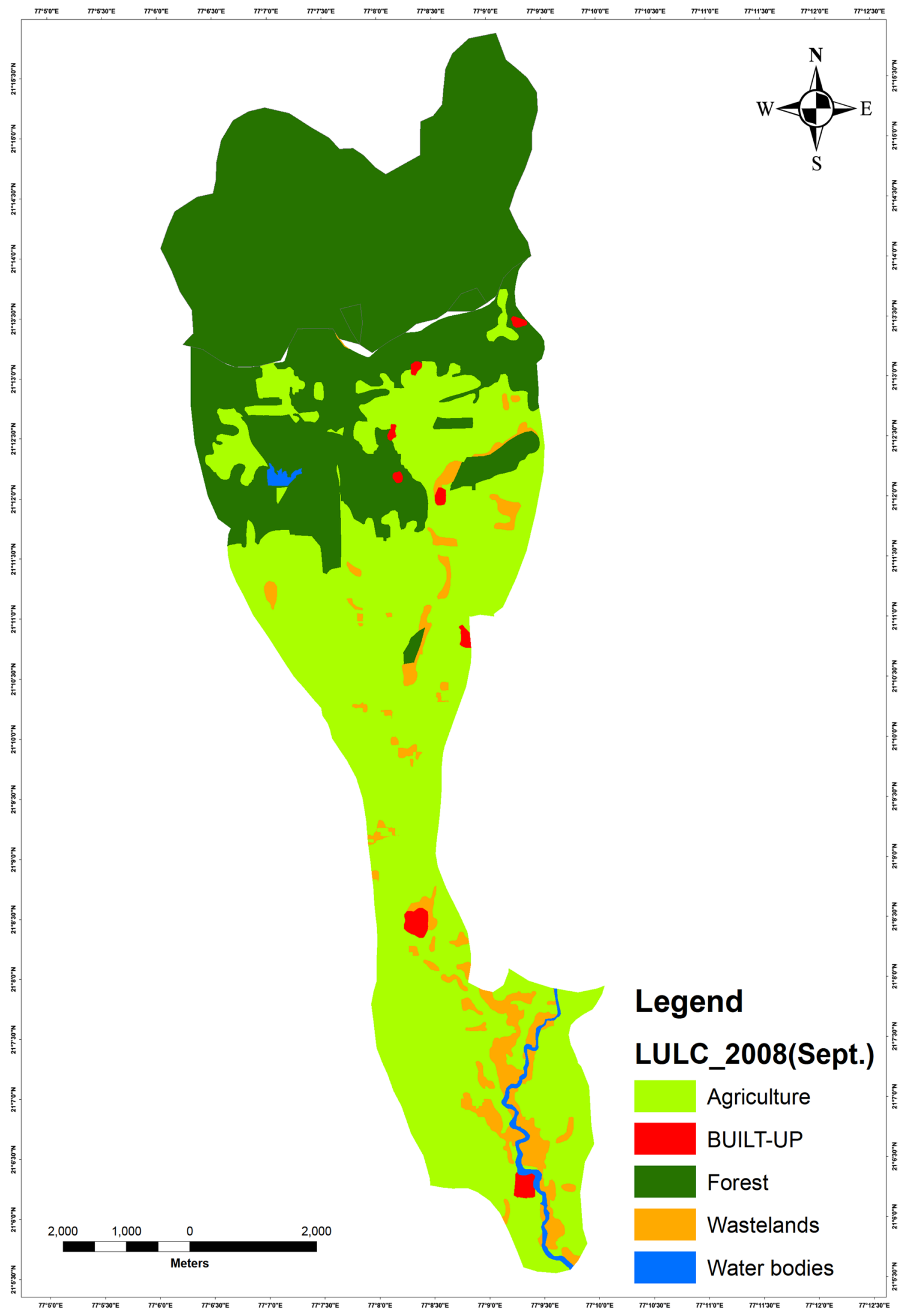

Fig. 3 Land use/land cover map of the Ruikhed watershed (September 2008) 


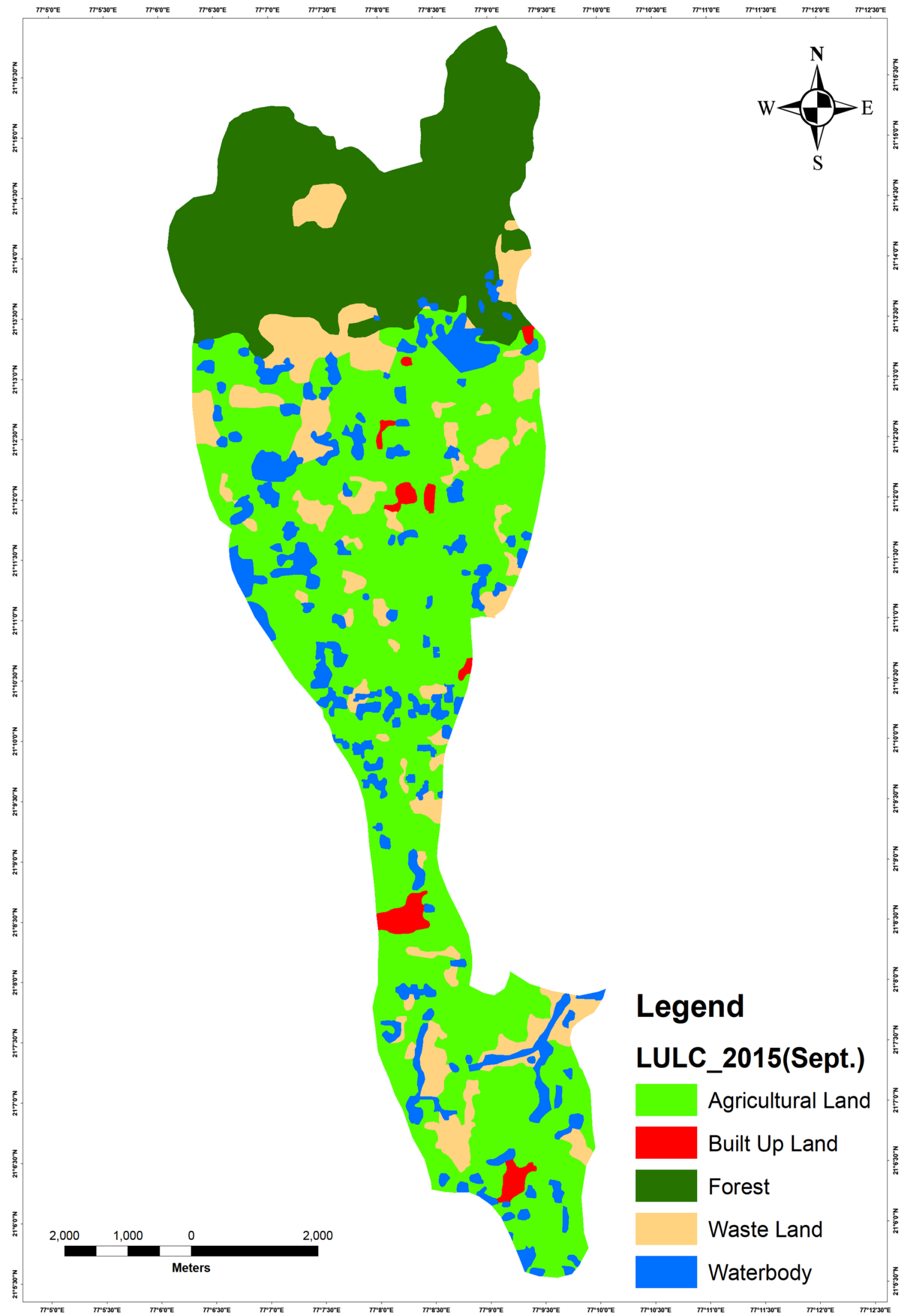

Fig. 4 Land use/land cover map of the Ruikhed watershed (September 2015) 
Table 3 Area and amount of change in patterns of land use/ land cover (area in hectares)

\begin{tabular}{|c|c|c|c|c|c|c|}
\hline \multirow[t]{2}{*}{ Land use/land classes } & \multicolumn{2}{|c|}{ September 2008} & \multicolumn{2}{|c|}{ September 2015} & \multicolumn{2}{|c|}{ Change 2008-2015 } \\
\hline & Area $(\mathrm{Ha})$ & Area $(\%)$ & Area (Ha) & Area $(\%)$ & Area (Ha) & $\%$ \\
\hline Wasteland & 272.40 & 4.50 & 693.29 & 11.50 & 420.89 & 7 \\
\hline Developed land & 38.00 & 0.62 & 83.78 & 1.39 & 45.78 & 0.56 \\
\hline Agricultural land & 2866.48 & 47.37 & 2997.25 & 49.74 & 130.77 & 2.37 \\
\hline Water bodies & 51.13 & 0.84 & 616.91 & 10.23 & 565.78 & 9.39 \\
\hline Forestland & 2797.57 & 46.42 & 1634.07 & 27.12 & -1163.5 & -19.3 \\
\hline Total area & 6025.58 & $100 \%$ & 6025.30 & $100 \%$ & 0.00 & 0.00 \\
\hline
\end{tabular}

The post-classification evaluation technique, which is the most common approach in change detection, was used for land use/cover maps. In order to manage mapping inaccuracies across different spatial resolutions, all the classified datasets were resampled to $30 \mathrm{~m}$ before proceeding with change analysis.

\section{Rate of land cover change}

The LULCC percentages were calculated using compound interest law formula (Puyravaud 2003; Pasha et al. 2016).

$r=\frac{1}{\left(t_{1}-t_{2}\right)} \times \ln \frac{a_{2}}{a_{1}}$

where $r$ is the annual rate of change (percentage per annum), and $a_{1}$ and $a_{2}$ are the land use/cover estimates at time $t_{1}$ and $t_{2}$, respectively.

\section{Results and discussion}

\section{Land use classification identification and change assessment using multi-temporal satellite data from 2008 to 2015}

The classified land use/cover maps of the Ruikhed watershed area for 2008 and 2015 are given in Figs. 3 and 4. The overall classification accuracy was 92.32 and $94.13 \%$, and total kappa statistics were 0.9437 and 0.9270 , for the 2008 and 2015 satellite images, respectively. According to Lea and Curtis (2010), accurate assessment recording requires total classification accuracy greater than $92 \%$ and kappa statistic greater than 0.94; thus the classification for the Ruikhed watershed area can be considered successful. The land use/ cover classification results for 2008 and 2015 are summarized in Table 3. LULCC analysis reveals a quantifiable trend in the failure and development of agricultural land. The results show that major failure with respect to area reporting in the Ruikhed watershed was observed in the water-body class, whereas the area of developed land, wasteland, and agriculture land increased. The forestland class decreased in satellite images from 2008 to 2015.

Figure 3 shows the spatial distribution patterns of land use/cover in the Ruikhed watershed in the Akola district for 2008 and Fig. 4 for 2015. The watershed area data for 2008 show the following distribution: $47.37 \%$ (2866.48 Ha) agricultural land, $46.42 \%(2797.57 \mathrm{Ha})$ forestland, $4.50 \%$ $(272.40 \mathrm{Ha})$ wasteland, $0.84 \%(51.13 \mathrm{Ha})$ water bodies, and $0.62 \%$ (38.00 Ha) developed land. For 2015, the data show 49.74\% (2997.25) agricultural land, 27.12\% (1634.07 Ha) forestland, $11.17 \%(693.29 \mathrm{Ha})$ wasteland, $1.39 \%(83.78 \mathrm{Ha})$ developed land, and $10.23 \%(616.91 \mathrm{Ha})$ water bodies (Table 3 ). These data (Table 3 and Figs. 3 and 4) reveal the occurrence of both positive and negative variations in land use/cover type in the Ruikhed watershed area. Between 2008 and 2015, agricultural land in the study area increased from 2866.48 to $2797.57 \mathrm{Ha}$, which accounts for $2.37 \%$ of the total study area.

Forestland was reduced from $2797.57 \mathrm{Ha}$ in 2008 to $1634.07 \mathrm{Ha}$ in 2015 , which accounts for $-19.3 \%$ of the total study area. Developed land increased from $38.00 \mathrm{Ha}$ in 2008 to $45.78 \mathrm{Ha}$ in 2015 , which accounts for $0.56 \%$. The water-body area increased from 51.13 to $616.91 \mathrm{Ha}$ between 2008 and 2015, which accounts for $9.39 \%$ of the total Ruikhed watershed area. Wasteland increased from 272.40 to $693.29 \mathrm{Ha}$ between 2008 and 2015, which accounts for $7 \%$ of the total watershed area (Figs. 5, 6).

\section{Conclusion}

This study of the Ruikhed watershed in the Akola district of Maharashtra, India, demonstrates that the use of spatial multi-temporal satellite data or imagery, with the aid of GIS and RS technology, can play a vital role in computing spatial and temporal phenomena, previously not possible through traditional digital mapping. Study area data reveal that agriculture represents the most important land use in the Ruikhed watershed, with an increase of $2.37 \%$ 


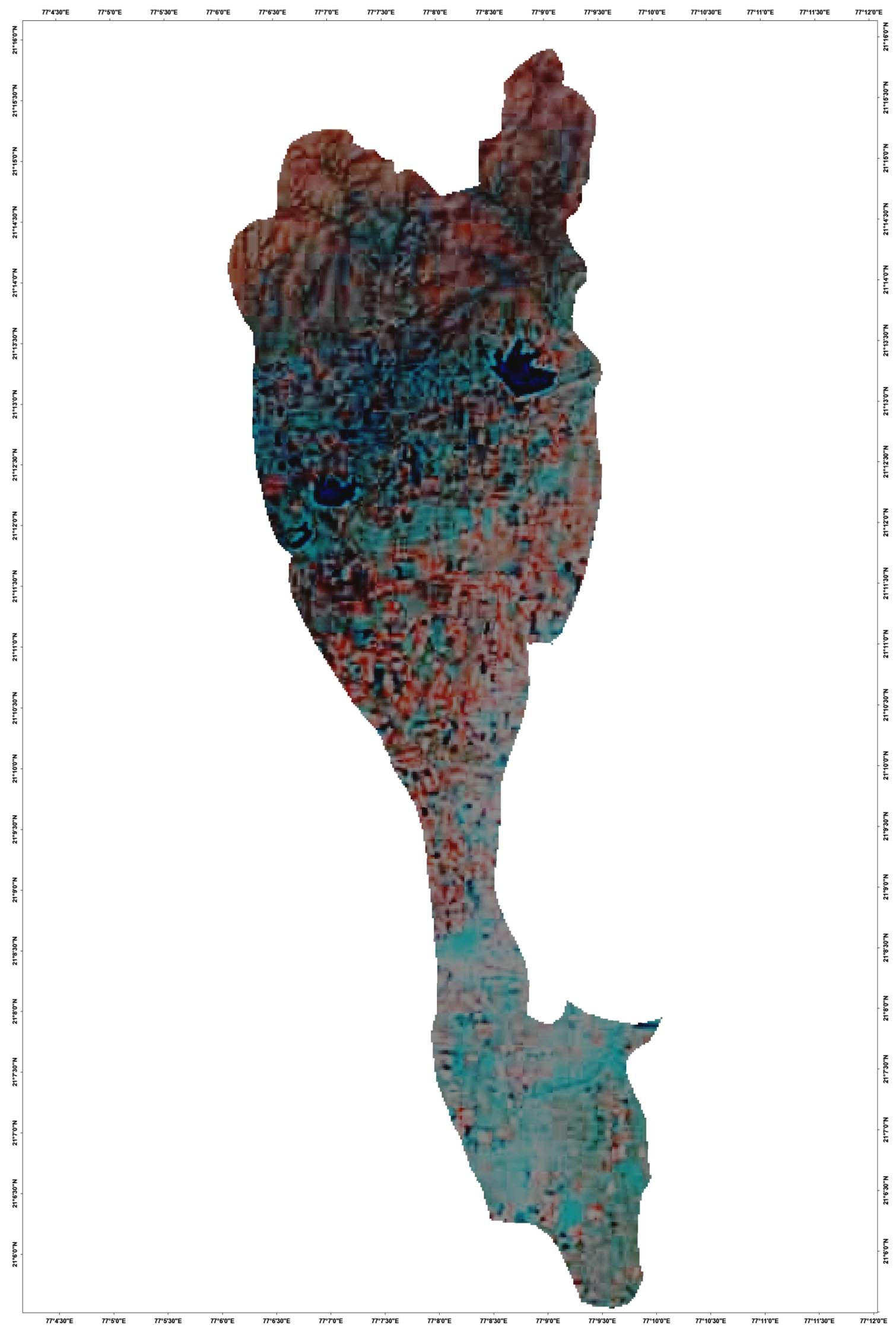

Fig. 5 Satellite image (LISS-III) of the Ruikhed watershed (September 2015) 
Fig. 6 Satellite image (LISSIII) of the Ruikhed watershed (September 2008)

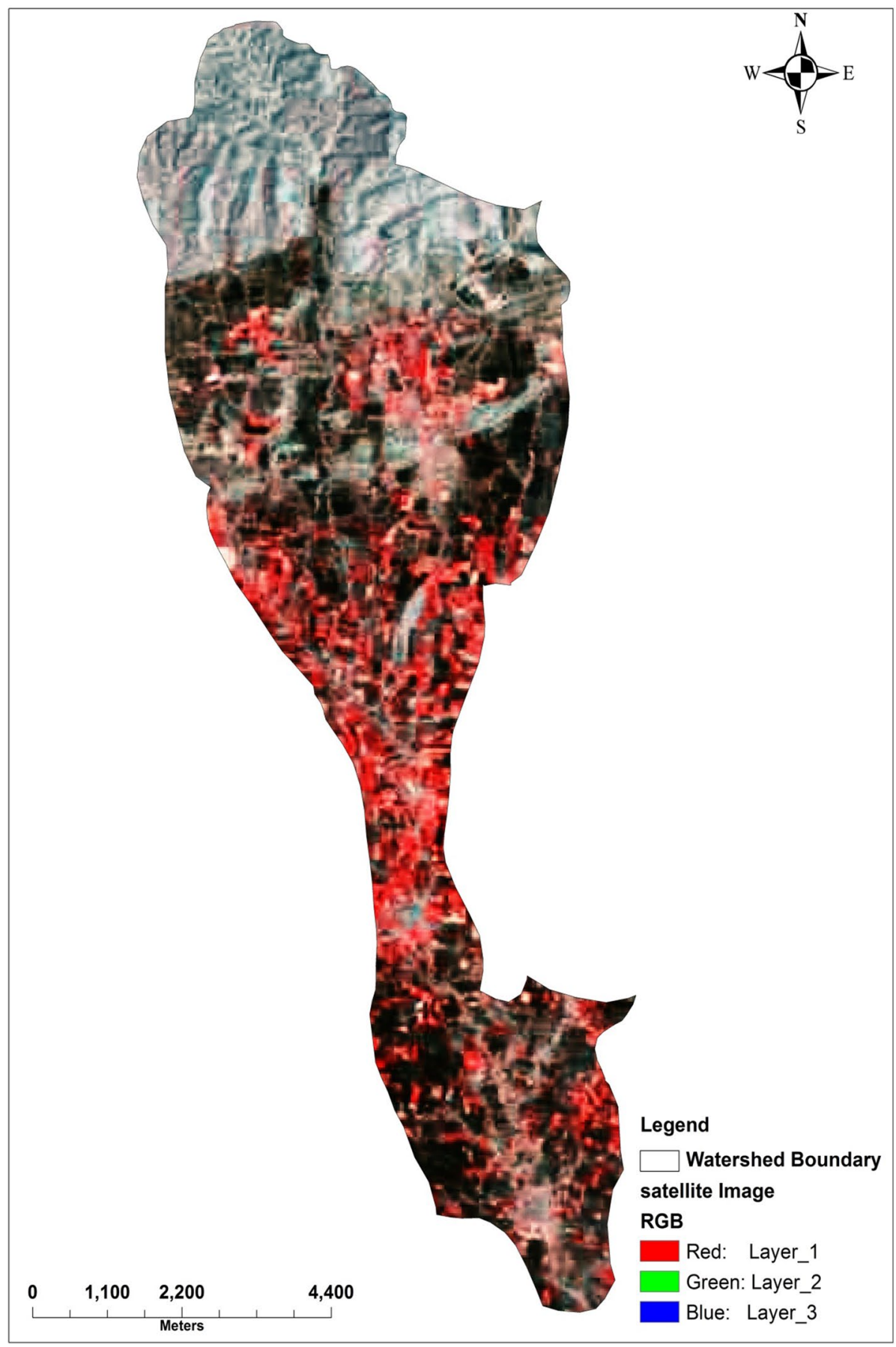


Fig. 7 Graph showing change detection for the period 2008-2015
Change Detection of Ruikhed

Watershed(2008-15)

2008 Area (\% age) 2015 Area (\% age)

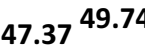

49.74
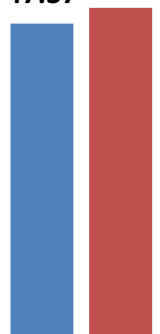

0.621 .39

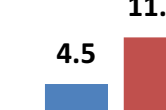

11.5

Waste Land

Built-Up Land Agricultural Land

10.23

0.84

Water Body
Fig. 8 Graph showing land use/land cover changes for the period 2008-2015
Land use/cover Changes (2008-15)

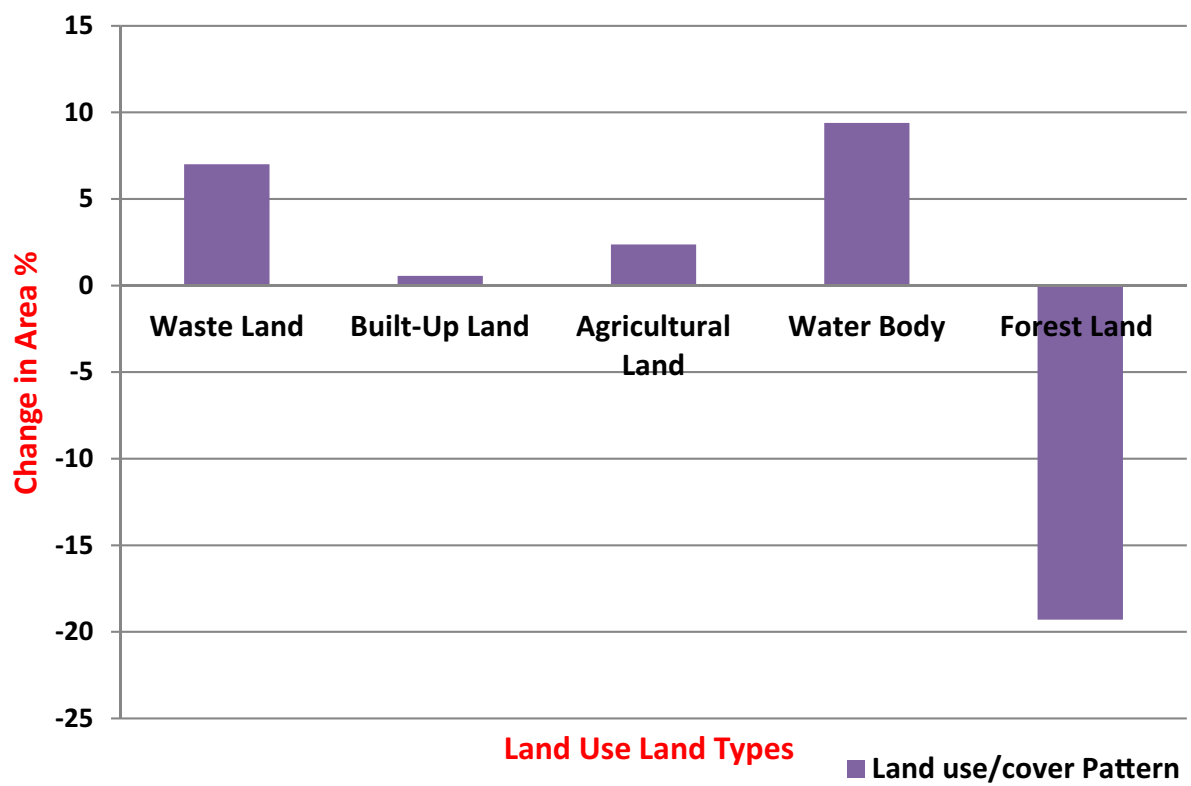

(130.77 Ha) from 2008 to 2015 as a result of soil and water conservation measures. The second major type of land use in the watershed area, forestland, was reduced by $19.3 \%$ $(1163.5 \mathrm{Ha})$ due to changes in the proportion of wasteland, agricultural land, and water bodies. The third major category, wasteland, increased by $7 \%$ (420.89 Ha) from 2008 to 2015 . The fourth category, developed land, increased by $0.56 \%(45.78 \mathrm{Ha})$, due mostly to growth of the village area over the last two decades. The fifth category, water bodies, increased by $9.39 \%(565.78 \mathrm{Ha})$ due to conversion of agricultural land and wasteland. The water increase is most important for agricultural land. Hence, proper management of these water resource is needed, because otherwise this valuable water resource will soon be lost or will no longer be able to play its full role in agricultural production and socioeconomic growth in the Ruikhed watershed area (Figs. 7, 8).

Thus, remote sensing and GIS techniques are effective technologies for the spatial-temporal changes analysis and quantification of land use and land cover classes, which is not possible with traditional techniques. These digital technologies are very easy to changes of LULC classes and this techonology is not time consuming process and very low cost, and with better accuracy.

Open Access This article is distributed under the terms of the Creative Commons Attribution 4.0 International License (http://creativeco mmons.org/licenses/by/4.0/), which permits unrestricted use, distribution, and reproduction in any medium, provided you give appropriate 
credit to the original author(s) and the source, provide a link to the Creative Commons license, and indicate if changes were made.

\section{References}

Agarwal C, Green GM, Grove JM, Evans TP, Schweik CM, (2001) A review and assessment of land-use change models dynamics of space, time and human choice. CIPEC collaborative report series no. 1. Center for the Study of Institutions Population, and Environmental Change Indiana University

Boori MS, Voženílek V, Choudhary K (2015) Land use/cover disturbance due to tourism in Jeseníky Mountain, Czech Republic: a remote sensing and GIS based approach. Egypt J Remote Sens Space Sci 18:17-26. https://doi.org/10.1016/ j.ejrs.2014.12.002.

Butt A et al (2015) Land use change mapping and analysis using remote sensing and GIS: a case study of Simly watershed, Islamabad, Pakistan. Egypt J Remote Sens Space Sci. https://doi. org/10.1016/j.ejrs.2015.07.003

Gao J, Liu Y (2010) Determination of land degradation causes in Tongyu County, Northeast China via land cover change detection. Int J Appl Earth Obs Geoinf 12(1):9-16

Kalaba FK, Quinn CH, Dougill AJ, Vinya R (2013) Floristic composition, species diversity and carbon storage in charcoal and agriculture fallows and management implications in Miombo woodlands of Zambia. For Ecol Manage 304:99-109

Lambin EF (1997) Modelling and monitoring land-cover change processes in tropical regions. Prog Phys Geogr 21:375-393. https:// doi.org/10.1177/030913339702100303

Lea C, Curtis AC (2010) Thematic accuracy assessment procedures: National Park Service Vegetation Inventory, version 2.0. Natural Resource Report NPS/2010/NRR 2010/204, National Park Service, Fort Collins, Colorado, USA

Lu D, Mausel P, Brondizio E, Moran E (2004) Change detection techniques. Int J Remote Sens 25:2365-2407

Myers N (1993) Tropical forests: the main deforestation fronts. Environ Conserv 20:9-16
Ozesmi SL, Bauer ME (2002) Satellite remote sensing of wetlands. Wetl Ecol Manage 10:381-402

Pande C, Moharir K (2014) Analysis of land use/land cover changes using remote sensing data and GIS techniques of Patur Taluka, Maharashtra, India. IJPRET 2(12):85-92

Pasha V et al (2016) Assessment of land cover change hotspots in Gulf of Kachchh, India using multi-temporal remote sensing data and GIS. J Indian Soc Remote Sens. https://doi.org/10.1007/s1252 4-016-0562-9

Puyravaud JP (2003) Standardizing the calculation of the annual rate of deforestation. For Ecol Manage 177:593-596

Rawat JS, Kumar M (2015) Monitoring land use/cover change using remote sensing and GIS techniques: a case study of Hawalbagh block, district Almora, Uttarakhand, India. Egypt J Remote Sens Space Sci 18:77-84

Rawat JS, Biswas V, Kumar M (2013) Changes in land use/cover using geospatial techniques-A case study of Ramnagar town area, district Nainital, Uttarakhand, India. Egypt J Remote Sens Space Sci 16:111-117

Rundquist DC, Narumalani S, Narayanan RM (2001) A review of wetlands remote sensing and defining new considerations. Remote Sens Rev 20:207-226

Turner MG, Gardner RH, O’Neill RV (2001) Landscape ecology in theory and practice pattern and process. Springer, New York

Verburg PH, van Eck JR, de Hijs TC, Dijst MJ, Schot P (2004) Determination of land use change patterns in the Netherlands. Environ Plan B Plan Des 31:125-150

Zhang S, Zhang S, Zhang J (2000) A study on wetland classification model of remote sensing in the Sangjiang Plain. Chin Geogr Sci 10:68-73

Publisher's Note Springer Nature remains neutral with regard to jurisdictional claims in published maps and institutional affiliations. 